\title{
Hekim Reçeteleri Doğru Uygulanıyor Mu?
}

\author{
Emine Güçer, Zahide Yalaki, Fatma İnci Arıkan, Yıldız Dallar \\ Ankara Eğitim ve Araştırma Hastanesi Çocuk Sağlığı ve Hastalıkları Kliniği, Ankara
}

\begin{abstract}
ÖZET
Hekim reçeteleri doğru uygulanıyor mu?

Farklı nedenlerden kaynaklanan yanlış ilaç uygulamaları hayati tehlike doğurabilecek kadar ciddi sonuçlara neden olabilmektedir. Burada ampisilin sulbaktam reçete edildiği halde amikasin uygulanan iki olgu sunulmuştur. ilk olguda bir yaşında erkek hastanın öksürük şikayetiyle çocuk acil polikliniğine getirildiği ve pnömoni tanısı konularak parenteral ampisilin sulbaktam reçete edildiği öğrenildi. illk üç dozu dış merkezde yaptıran hasta dördüncü dozu yaptırmak üzere hastanemize başvurduğunda hemşire tarafından yapılacak ilacın ampisilin yerine amikasin olduğunun anlaşılması üzerine hasta amikasin intoksikasyonu tanısıyla takip ve tedavi amaçlı yatıııldı. ikinci olguda ise yedi aylık erkek hastanın ateș, öksürük şikayetiyle çocuk acil polikliniğine getirildiği ve pnömoni tanısı ile parenteral ampisilin sulbaktam reçete edildiği öğrenildi. Ilacın iki dozunu dış merkezde yaptıran hasta kusma şikayetinin olması nedeniyle çocuk polikliniğine getirildiğinde, aileden alınan anamnezde ilaç uygulamasından sonra kusmalarının olduğunun saptanması üzerine ilaç kontrol edildi. Hastaya eczanede ampisilin yerine amikasin verildiği fark edildi. Hasta amikasin intoksikasyonu tanısıyla takip ve tedavi amaçlı yatırıldı. Reçeteler yazılırken okunaklı olması konusunda doktorların özen göstermeleri, eczacıların da ilaçları verirken, hemşirelerin ilaçları uygularken daha dikkatli olmaları gerektiğini düşünmekteyiz.
\end{abstract}

Anahtar kelimeler: Aminoglikozit, yanlış ilaç, amikasin

\section{ABSTRACT \\ Are doctors' prescriptions applied accurately?}

Misapplication of a drug prescription as a result of various reasons may cause serious, even life-threatening consequences. This case report presents two examples of such situations in which Amicasin was applied instead of the prescribed Ampicillin Sulbactam. The role of the doctor, nurse and the pharmacists in these situations was also discussed. In case one; a one year old boy patient who came to our clinic with complaints of cough was given a prescription of parenteral Ampicilline Sulbactam with a diagnosis of pneumonia. The first three doses were given to the patient in a different health center and when the patient applied to our hospital for the fourth dose, it was realized by the nurse that the medicine the patient was given previously was Amicasin instead of Ampicillin. Consequently, the patient was admitted to the hospital for follow up and treatment with the Amicasin intoxication. In the second case; a 7 months old boy patient who came to our pediatric emergency department with complaints of cough and fever was prescribed parenteral Ampicilline Sulbactam with a diagnosis of pneumonia. The first two doses were given in a different health center and since then the patient had complaints of vomiting. When he came to our hospital, the previously applied medicine was checked and, it was realized that the patient was given Amicasin instead of Ampicillin in the pharmacy. The patient admitted to the hospital for follow up and treatment with the Amicasin intoxication. We conclude that it is very important for doctors to write the prescriptions in a clear and readable way, for pharmacists' to give the medicines carefully, and for nurses to be very careful during the application process of the medicines.

Key words: Aminoglycoside, wrong drug, amicasine

Bakırköy Tıp Dergisi 2012;8:194-196

\section{GíRiş}

A minoglikozitler Gram (-) bakterilere etkili protein sentez inhibisyonu ile etkinlik gösteren antibiyotiklerdir. Nefrotoksik, nörotoksik, ototoksik yan etkileri vardır. Bu yan etkileri teröpotik dozlarda dahi görülen bu ilaç grubunun yüksek dozlardaki kullanımı ile ilgili yeterli veri yoktur. Burada reçetenin yanlış okunmasına bağlı yüksek doz amikasin kullanılan iki olgu sunulmuştur.

Yazışma adresi / Address reprint requests to: Dr. Zahide Yalakı Ankara EAH Çocuk Sağlığı ve Hastalıkları Kliniği, Mamak, Ankara

Telefon / Phone: +90-506-407-9866

Elektronik posta adresi / E-mail address: dr_zahide@yahoo.com Geliş tarihi / Date of receipt: 02 Şubat 2011 / February 02, 2011

Kabul tarihi / Date of acceptance: 06 Eylül 2011 / September 06, 2011

\section{OLGU SUNUMU 1}

Bir yaşında erkek hastanın başvurudan iki gün önce başlayan öksürük, ateş, hızlı nefes alma şikayetiyle çocuk acil polikliniğine getirildiği ve pnömoni tanısı konularak parenteral ampisilin-sulbaktam (500 mg flakon) 12 saatte bir kullanmak üzere reçete edildiği öğrenildi. ilacın ilk üç dozunu dış merkezde yaptıran hasta, dördüncü dozu yaptırmak üzere getirildiği çocuk acil polikliniğinde hemşire tarafından yapılacak ilacın ampisilin yerine amikasin olduğunun anlaşılması ve birinci gün $111.1 \mathrm{mg} / \mathrm{kg} /$ gün, ikinci gün $55.5 \mathrm{mg} / \mathrm{kg} /$ gün amikasin alması nedeniyle amikasin intoksikasyonu tanısıyla takip ve tedavi amaçlı yatırıldı.

Hastanın gelişinde yapılan fizik muayenesinde vücut 
ağırlığı 9 kg (10-25p), boyu 69cm (50p), baş çevresi $46 \mathrm{~cm}$ (25p) bulundu. Sistem muayenelerinde solunum seslerinin kaba olması dışında patolojik bulgu saptanmadı. Laboratuar incelemesinde hemogram, karaciğer ve böbrek fonksiyon testleri normaldi. Yapılan işitme testinde ve göz muayenesinde patolojik bulgu saptanmadı. İzleminde böbrek ve karaciğer fonksiyonları normal sınırlarda seyreden hasta ayaktan çocuk nefroloji polikliniği ve kulak burun boğaz polikliniği tarafından takip edilmek üzere taburcu edildi. Hastanın 6 aylık izleminde böbrek fonksiyonları bozulmadı.

\section{OLGU SUNUMU 2}

Yedi aylık erkek hastanın başvurudan iki gün önce başlayan ateş, öksürük şikayetiyle çocuk acil polikliniğine getirildiği ve pnömoni tanısı konularak parenteral ampisilin-sulbaktam (500 mg flakon) 12 saatte bir kullanmak üzere reçete edildiği öğrenildi. illacın iki dozunu dış merkezde yaptıran hasta kusma şikayetinin olması nedeniyle çocuk polikliniğine getirildiğinde, aileden alınan anamnezde ilaç uygulamasından sonra kusmalarının olduğunun saptanması üzerine ilaç kontrol edildi. Hastaya eczanede ampisilin yerine amikasin verildiği fark edildi. 131.5 mk/kg/gün amikasin alan hasta amikasin intoksikasyonu tanısıyla takip ve tedavi amaçlı yatırıldı.

Hastanın yatışında yapılan fizik muayenesinde vücut ağırlığı 7.6 kg (25-50p), boyu 70cm (50-70p), baş çevresi $44 \mathrm{~cm}$ (50p) bulundu. Sistem muayenelerinde solunum sesleri kaba, ekspiryumu uzun ve bilateral ronkus saptandı. Diğer sistem muayeneleri doğaldı. Yatışında bakılan hemogram, karaciğer fonsiyonları ve böbrek foksiyon testleri normaldi. Yapılan işitme testi ve göz muayenesinde patolojik bulgu saptanmadı. Pnömonisi tedavi edilen izleminde böbrek ve karaciğer fonksiyonları normal seyreden hasta ayaktan çocuk nefroloji polikliniği ve kulak burun boğaz polikliniği tarafından takip edilmek üzere taburcu edildi. Hastanın 6 aylık izleminde böbrek fonksiyonları bozulmadı.

\section{TARTIŞMA}

Aminoglikozitler Gram(-) bakterilere etkili protein sentez inhibisyonu ile etkinlik gösteren antibiyotiklerdir. Nefrotoksik, nörotoksik, ototoksik yan etkileri vardır (1). Nefrotoksik etkisi ilaç kesilince düzelmesine karşın ototoksik etkisi irreversibldir (2). Yapılan çalışmalarda ami- noglikozitlerin teröpatik dozlarda erișkin ve çocuk hastada \% 5-20 oranında renal toksisite ile ilişkisi bulunmuştur.

Aminoglikozidler nefrotoksik etkisini proksimal tübüldeki epitel hücrelerine bağlanarak gösterirler (3). Yüksek doz ve uzun süreli tedavide risk artmaktadır. Amikasinin tedavi dozu $15 \mathrm{mg} / \mathrm{kg} /$ gün'dür. Bizim olgularımızdan birincisine $100 \mathrm{mg} / \mathrm{kg} /$ gün, ikincisine $125 \mathrm{mg} / \mathrm{kg} /$ gün dozunda amikasin verilmiştir. Bu yüksek dozları kısa süreli alan hastalarımızda böbrek yetmezliği gelişmemiştir ancak bu dozda amikasin uygulamasının literatürde örneği yoktur.

Vestübulotoksik ve kohleatoksik olarak iki ayrı şekilde ototoksik etki göstermektedir. Ototoksisite sıklığının yetişkinlerde \%2-45 ve infantlarda \%0-2 olduğu bilinmektedir (4). Vestibulotosik etkisi reversibldir. Altı aya kadar düzelebilir. Kohleatoksik etkisi irreversibldir. Klinikte işitme kaybı olarak ortaya çıkan kohleatoksisite \%33; baş dönmesi, tinnitus şeklinde ortaya çıkan vestibulotoksisite \%15 olarak rapor edilmiştir (5). Bizim hastalarımız tedaviyi kısa süreli almış olmalarına rağmen toksik dozda aldıkları ve çocuk hasta oldukları için özellikle ototoksisite açısından yakın takibe alınmışlardır.

Pediatride hatalı ilaç uygulamaları sağlık zincirinde çeşitli aşamalardaki aksaklık sonucu oluşmaktadır. Doktorların okunaksız yazı yazması, eczanelerde eczacı yerine eğitimsiz kalfaların ilaçları vermesi, dikkatsiz ve pediatrik ilaç uygulamaları konusunda deneyimsiz ve eğitimsiz hemşirelerin pediatri servislerinde çalıştırılması yaşanan yanlış uygulamalara sebep olmaktadır.

Bizim olgularımızda ilk 2 doz uygulamasında reçete edilen ilaç ile eczaneden verilen ilacın farklı olduğu hemşire tarafından fark edilmemiş, üçüncü doz uygulamasında başka bir hemşire tarafından yanlışlık fark edilmiştir. Bu durumda göstermektedir ki yanlış ilaç uygulamalarında ve engellenmesinde de hemşirelerin rolü büyüktür.

Hekimlere yapılan okunaksız el yazısı ile ilgili anket çalışmasında katılımcıların \%25.7'si okunaksız el yazısının yanlış ilaç uygulamalarına sebep olduğunu, \%26'sı okunaksız el yazısının tedavide gecikme ve zaman kaybına yol açacağını düşündüklerini belirtmiştir. Yine aynı anket çalışmasında okunaksız reçete sorununu çözümünde katılımcıların \%38.5'ihekimlere bu konunun önemini vurgulayan hizmet içi eğitimlerin verilmesi gerektiği,\%28.3'ü ise bilgisayar çıktısı kullanılması gerektiği sonucuna varmiştır (6).

Okunaksız yazı yazma bir hekimlik geleneği değildir. Özellikle pediatrik hasta popülasyonunda ilaçların daha 
kolay toksik etki yapacağı düşünülürse pediatristler bu konuda daha dikkatli olmalıdır.

Eczacılar pediatrik hastaların reçetelerinde daha özenIi davranmalıdır. Bizim olgularımızda eczane reçeteyi yanlış okusa bile verdiği ilacın çocuk hasta için teröpatik dozun çok üstünde olduğunu fark etmemiştir. Bu durum eczanelerin kalfaların eline bırakılmasının kaçınılmaz

\section{KAYNAKLAR}

1. De Jager $P$, van Altena R. Hearing loss and nephrotoxicity in long term aminoglycoside treatment in patients with Tuberculosis. Int J Tuberc Lung Dis 2002; 6: 622-627.

2. Aygün G. Akılcl Antibiyotik Kullanımı ve Erişkinde Toplumdan Edinilmiş Enfeksiyonlar Sempozyum Dizisi. iÜ Cerrahpaşa Tıp Fakültesi, Sürekli Tıp Eğitimi Etkinlikleri. 2002; 31: 39-54.

3. Mingeot-Leclercq MP, Tulkens PM. Aminoglycosides: Nephrotoxicity. Antimicrob Agents Chemother 1999; 43: 1003-1012. sonuçlarındandır.

Sonuç olarak pediatrik hastalar ilaç seçimi ve uygulanan doz bakımından dikkat edilmesi gereken bir gruptur. Reçeteler yazılırken okunaklı olması konusunda doktorların özen göstermeleri, eczacıların da ilaçları verirken, hemşirelerin ilaçları uygularken daha dikkatli olmaları gerektiğini düşünmekteyiz.

4. Fausti SA, Henry JA, Schaffer HI, Olson DJ, Frey RH, McDonald WJ. High-frequency audiometric monitoring for early detection of aminoglycoside ototoxicity. J Infect Dis 1992; 165: 1026-1032.

5. Chen Y, Huang WG, Zha DJ, Qiu JH, Wang JL, Sha SH. Aspirin attenuates gentamicin ototoxicity: from the laboratory to the clinic. Hear Res 2007; 226: 178-182.

6. Aşçıŏlu F. Cantürk G. Hekimlerin Okunaksız El Yazısının Yol Açtığı Sorunlar: Bir Anket Çalıșması. Adli Bilimler Dergisi 2003; 2: 13-22. 